НАУКОВИЙ ВІСНИК

Scientific messenger of Livi National University of
Veterinars Meditive and Biotechnologies

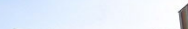

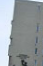

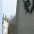

RRES: VETERINARY SCENC
Науковий вісник Аьвівського національного університету ветеринарної медицини та біотехнологій імені С.3. Гжицького. Серія: Ветеринарні науки

Scientific Messenger of Lviv National University of Veterinary Medicine and Biotechnologies. Series: Veterinary sciences

UDC 619:612.015.3:637.4:636.5

\title{
Overview: prevalence and structure of metabolic diseases of laying chickens, their influence on egg quality and condition of young chickens
}

\author{
A. R. Shcherbatyy, L. G. Slivinska
}

Stepan Gzhytskyi National University of Veterinary Medicine and Biotechnologies Lviv, Ukraine

Article info

Received 06.09.2021

Received in revised form 11.10.2021

Accepted 12.10.2021

Stepan Gzhytskyi National University of Veterinary Medicine and Biotechnologies Lviv, Pekarska Str., 50, Lviv, 79010, Ukraine. Tel.: +38-097-758-07-19 E-mail: ua-andrea@ukr.net
Shcherbatyy A. R., Slivinska L. G. (2021). Overview: prevalence and structure of metabolic diseases of laying chickens, their influence on egg quality and condition of young chickens. Scientific Messenger of Lviv National University of Veterinary Medicine and Biotechnologies. Series: Veterinary sciences, 23(104), 3-9. doi: 10.32718/nvlvet10401

The article analyzes and presents statistics on the number of laying hens in Ukraine, production, consumption and import of eggs for the last 5 years, the spread of metabolic diseases of laying hens on the basis of a review of literature sources. Metabolic disorders are the largest group of poultry diseases classified as metabolic diseases and cause significant economic losses. Hepatitis, hepatodystrophy, cirrhosis, liver abscesses, cholecystitis, and gallstone disease are diagnosed in laying hens as a result of impaired carbohydrate, lipid, protein, and mineral metabolism. With a lack or imbalance of calcium and phosphorus or D-hypovitaminosis, in chickens develop diseases such as osteoporosis and hypocalcemia, which reduce egg-laying, quality of hatching eggs and young poultry, and can lead to the death of embryos and adults. Hypovitaminosis $(A, D, E)$ and microelementosis $(\mathrm{Co}, \mathrm{Cu}, \mathrm{Zn}, \mathrm{J})$ in poultry cause decreased immunity, disorders of hormonal system, growth, reproductive functions, egg production, dysfunction of internal organs and nervous system, contribute to the formation of defective eggs, development in embryo of alimentary diseases, which affects the hatchability and quality of young poultry. In view of this, the norms of feeding and keeping poultry are constantly being improved based on an in-depth study of these processes. The subject of this work was a comparative review of the results obtained by various authors on the most common metabolic diseases of laying hens, their impact on productive traits (laying), quality characteristics of eggs, embryogenesis, quality of young laying hens of modern high-yielding crosses. This review of literature sources can serve as a tool for determining the future direction of research, as well as an indicator of its practical application.

Key words: metabolism, poultry, productivity, incubation

\section{Огляд: поширеність і структура метаболічних хвороб курей-несучок, їх вплив на якість яєць і молодняку}

\author{
А. Р. Щербатий, Л. Г. Слівінська
}

Львівський національний університет ветеринарної медицини та біотехнологій імені С. 3. Гюицького, м. Львів, Украӥна

У статті проаналізовано і наведено статистичні дані щуодо поголів'я птиці в Украйні, виробництво, споживання та імпорт яєиь за останні 5 років, поширення метаболічних хвороб курей-несучок на основі проведеного огляду літературних джерел. Метаболічні патології становлять найбільшу групу захворювань домашньої птиці, класифікованих як порушення обміну речовин, або метаболічні хвороби, і спричиняють значні економічні збитки. Внаслідок порушення вуглеводного, ліпідного, протеїнового та мінерального обмінів в курей-несучок діагностують гепатит, гепатодистрофію, ичроз, абсцеси печінки, холецистит і жовчнокам'яну хворобу. За нестачі або дисбалансу Кальиію та Фосфору, D-гіповітамінозу у курей виникають такі хвороби, як остеопороз і гіпокальиіємія, які знижують несучість, якість інкубаційних яєць та молодняку і можуть спричинити загибель ембріонів та дорослого поголів'я. Гіповітамінози (A, D, E) та мікроелементози (Co, Cu, Zn, J) у птиці викликають зниження імунітету, пору- 
шення гормональної системи, росту, репродуктивної функиії, несучості, роботи внутрішніх органів і нервової системи, спричиняють утворення неповноцінних яєць, розвиток в ембріона аліментарних захворювань, шуо впливає на виводимість і якість молодняку. 3 огляду на ие постійно триває удосконалення норм годівлі та утримання птиці на основі поглибленого вивчення ичих прочесів. Предметом даної роботи є провести порівняльний огляд результатів, отриманих різними авторами, щуодо найпоширеніших метаболічних хвороб курей-несучок, їхній вплив на продуктивні ознаки (несучість), якісні характеристики яєць, ембріогенез, якість молодняку курей-несучок сучасних високопродуктивних кросів. Даний огляд літературних джерел може служити інструментом для визначення майбутнього напрямку досліджень, а також показником його практичного застосування.

Ключові слова: птиця, продуктивність, інкубачія, обмін речовин.

\section{Вступ}

Вітчизняне птахівництво є одним із найбільш економічно привабливих та конкурентоспроможних видів агробізнесу, на що вказує стійка динаміка зростання виробництва м'яса птиці і яєць. На сучасному етапі соціально-економічного розвитку в умовах постійного зростання цін на продовольчі товари продукція галузі птахівництва $є$ важливим елементом раціону харчування більшої частини населення (Lopatyn, 2012; Tsaruk, 2017). Птахівництво є найбільш швидкозростаючим та гнучким серед усіх галузей тваринництва. Дана галузь, насамперед завдяки дуже сильному попиту, розширилася, консолідувалася та глобалізувалася за останні 15 років у країнах усіх рівнів доходу. Не виняток і Україна. Як вказують (Tsaruk, 2017; Meleniuk, 2021), Україна має великі перспективи у розвитку птахівництва. Кернасюк Ю. В. (Kernasiuk, 2018), аналізуючи чисельність поголів'я птиці в Україні, зазначає, що на початку 2000 -х років в усіх категоріях господарств налічувалося лише 123,7 млн голів птиці, у 2015 р. іiї чисельність зросла до 214,6 млн, або майже в 1,7 раза, в 2021 році - 107,8 млн голів птиці. В особистих селянських господарствах скорочення поголів'я було менш помітним (-1,7 \% у річному обчисленні). На сьогодні в господарствах налічується 84,7 млн голів птиці, проте з січня цього року скорочення поголів'я склало 6,8 \%. Найбільше свійської птиці утримується у Вінницькій (32,2 млн голів), Черкаській (23,6 млн) та Київській (23,1 млн) областях.

За інформацією Союзу птахівників України, в нашій країні протягом 2015 року виробництво яєць складало 16,8 млрд штук. За 2020 рік виробництво яєць в Україні зменшилося на 2,9 \% порівняно з 2019 роком - до 16,2 млрд штук і частка склала близько 1,5 \% всіх отриманих яєць у світі. На даний час Україна входить до групи світових лідерів виробників курячих яєць і займає в міжнародному рейтингу почесне 11 місце. Так, у 2018 році Україна експортувала рекордні 1,7 млрд штук яєць, що на 21 \% більше, ніж у 2017, коли було експортовано 1,48 млрд шт. У грошовому вимірі експорт виріс на 37 \% і досяг рівня 94,1 млн доларів США. А в 2019 році, за даними Державної митної служби, на експорт відправили 137,1 тис. тонн яєць, що на 27,5 \% більше, ніж у 2018 (Kopytets \& Voloshyn, 2016). За даними Державної митної служби, в 2021 році Україна відправила на експорт 27,3 тис. тонн яєць. У грошовому еквіваленті експорт яєць за сім місяців цього року приніс $\$ 28,4$ млн. Головними покупцями українських яєць в січні-липні 2021 року було ОАЕ $(37,9 \%)$, Латвія $(25,5$ \%) і Саудівська Аравія $(6,9 \%)$.
Сучасна технологія промислового вирощування птиці пов'язана зі значним функціональним навантаженням на іiї організм. Це призводить до порушення обміну речовин і розвитку метаболічних хвороб, які складають до 90 \% внутрішньої патології.

Як стверджує Кирилів Б. Я. (Kyryliv \& Ratych, 2001), птиця сучасних високопродуктивних кросів $\mathrm{i}$ ліній особливо чутлива до негативного впливу технологічних та стресових чинників, які призводять до певних відхилень метаболізму і фізіологічних функцій. Як зазначає автор, актуальним є проведення системних досліджень із з'ясування фізіологобіохімічних особливостей росту і розвитку птиці, що дасть можливість розробити методи регуляції метаболічних процесів та поліпшити якість продукції (яєць і м'яса).

За даними авторів (Levchenko et al., 2017; 2019), хвороби обміну речовин умовно поділяють на чотири групи: 1) хвороби, спричинені порушенням вуглеводно-ліпідного і білкового обміну; 2) хвороби, зумовлені порушенням обміну макроелементів; 3) хвороби, що спричинені нестачею або надлишком мікроелементів; 4) гіповітамінози.

Виникнення метаболічних хвороб пов'язано з якістю та режимом годівлі птиці на великих промислових комплексах (Yousefi et al., 2005; Vodolazhchenko, 2011; Verner, 2013; Novozhylova, 2014). Використання для годівлі птиці різноманітних сорбентів, пре- та пробіотиків, біогенних стимуляторів росту, біологічно активних речовин стало невід'ємною складовою рецептур комбікормів (Leeson, 1999; Mashkin, 2010; Stoyanovskyy et al., 2020; Yaremchuk et al., 2020). Проте навіть такі заходи не убезпечують птицю від метаболічних хвороб.

Особливо актуальною залишається проблема збереження метаболічного гомеостазу організму курейнесучок з метою їх ефективної життєдіяльності за дії негативних антропогенних факторів в умовах сучасного птахівництва, таких як незадовільна екологічна ситуація, недостатня і неповноцінна годівля, порушення умов утримання (Bicudo et al., 2010; Antonenko et al., 2017; Yaremchuk et al., 2020).

\section{Результати та їх обговорення}

Найбільш поширеними патологіями серед курейнесучок є гепатодистрофія - 70-80\%, сечокислий діатез від 40 до $70 \%$; субклінічний перебіг А- і Егіповітамінозів (до $80 \%$ ), хвороби опорно-рухового апарату (30-35 \%) (Melnyk, 2008; 2015).

В організмі птиці всі види обміну речовин тісно пов'язані між собою, тому будь-яке захворювання 
спричиняе порушення гомеостазу, але провідним у виникненні захворювання $є$ порушення одного або двох видів обміну (Levchenko et al., 2017; 2019). Кілька факторів можуть спричинити посилене відкладення жиру в клітинах печінки, включаючи високу несучість яєць, токсини, дисбаланс поживних речовин, надмірне споживання високоенергетичних дієт, дефіцит поживних речовин, які мобілізують жир з печінки (ліпотропні агенти), ендокринний дисбаланс та генетичні компоненти. У несучок дана хвороба $є$ результатом надмірного накопичення жирів, коли порушується транспорт ліпопротеїнів (Roberts, 2004).

У високопродуктивних кросів курей-несучок центральним органом гомеостазу є печінка, яка працює в особливо напруженому режимі, оскільки бере участь в обміні протеїнів, вуглеводів, ліпідів, вітамінів, макро- і мікроелементів, жовчоутворення та жовчовиділення (Yaremchuk \& Slivinska, 2019; Gutyj et al., 2019; Ostapyuk et al., 2021; Tilbrook \& Fisher, 2020; Underwood et al., 2021).

У структурі внутрішніх незаразних хвороб птиці патологія печінки складає від 5 \% до 50,8\% (Bilokon et al., 2010; Ostapyuk \& Gutyj, 2019; Bashchenko et al., 2020).

Серед них діагностують: гепатит, гепатодистрофію, цироз, абсцеси печінки, холецистит і жовчнокам'яну хворобу. Особливий інтерес науковців спостерігається у вивченні обміну ліпідів, що пов'язано 3 багатогранними його функціями в метаболічних процесах організму (Kyryliv \& Ratych, 2001; Yaremchuk \& Slivinska, 2019).

У курей-несучок, зокрема серед внутрішніх хвороб, гепатодистрофії є найбільш поширеними і супроводжуються тяжким перебігом захворювання (Horzheiev, 2014; Levchenko et al., 2019; Yaremchuk et al., 2020).

3 огляду на це постійно триває удосконалення норм годівлі та утримання птиці на основі поглибленого вивчення вуглеводного, ліпідного, протеїнового та мінерального обміну.

Dunkle C. (2009) виділяє синдром жирової печінки, який $є$ одним 3 найважливіших метаболічних порушень, що спостерігаються у пік продуктивності у курей-несучок. Справжня причина захворювання досі незрозуміла, і першою ознакою часто $є$ збільшення смертності в стаді.

За даними ряду авторів (Lee et al., 1975; Hansen \& Walzem, 1993; Zon \& Ivanovska, 2016), виникнення жирової дистрофії, або так званого синдрому жирної печінки, найчастіше пов'язано з високою інтенсивністю яйцекладки. Також ймовірними причинами є склад та поживна цінність кормів (надлишкова енергія корму, вміст та походження білка корму, низький рівень Кальцію, при домінуванні кукурудзяної дієти, за низького рівня вітамінів Е та мінералів $\mathrm{Zn}, \mathrm{Fe}, \mathrm{Cu}, \mathrm{Mg}$ ), невідповідність раціону вікові та фізіологічним потребам птиці.

Гіповітамінози птиці, особливо несучок, широко розповсюдженні у господарствах усіх форм власності та завдають значних збитків, оскільки впливають на імунітет, ріст, розмноження, несучість, роботу внут- рішніх органів і нервової системи. Від них залежить нормальний розвиток птахів загалом та їхня висока продуктивність. Для несучок найбільш характерні А-, D- i E- гіповітамінози (Zang et al., 2011; Levchenko et al., 2017).

Як вказує (Lima \& Souza, 2018), А-гіповітаміноз у курей-несучок характеризується посиленою метаплазією і ороговінням епітеліальних клітин шкіри та слизових оболонок, порушенням зору та росту молодняку. У несучок пір'я стає матовим і скуйовдженим, спостерігається загальне пригнічення, знижується апетит, вгодованість, жива вага і несучість, дзьоб і кінцівки бліді, шкіра суха, слизове виділення з очей, 3 носових ходів виділяється серозно-слизовий ексудат (Raxmonov \& Norboev, 2019). Особливістю симптомів у несучок $\epsilon$ накопичення в кон'юнктивальних мішках сироподібного ексудату, збільшення підочних синусів. У яйцях, які вони несуть, жовток містить низьку кількість ретинолу і каротиноїдів.

D-гіповітаміноз - хронічне захворювання птиці усіх видів, що супроводжується порушенням кальцієво-фосфорного обміну i росту кісток. За даними Dunkle C. (2009), часто у високопродуктивних кросів несучок діагностується рахіт, який викликаний дефіцитом або дисбалансом циркулюючого Кальцію, вітаміну $\mathrm{D}_{3}$ та Фосфору. $\mathrm{y}$ дорослої птиці Dгіповітаміноз перебігає у формі остеомаляції і нерідко остеопорозу, декальцинацією кісток і яєчної шкаралупи. За дослідженнями (Turgut et al., 2006), велике значення в етіології рахіту має нестача в раціоні вітаміну А і недостатне співвідношення лужних і кислотних еквівалентів. За дослідженнями Vieth (1990), дефіцит вітаміну $\mathrm{D}_{3}$ у раціонах маточного поголів'я часто викликає рахіт у молодняку. Крім цього, надлишок вітаміну D токсично може діяти на ендокринну систему і викликати у молодняку низку захворювань.

Натомість Jefferson R. (2005) стверджує, що основними причинами остеопорозу та гіпокальціємії у курей $є$ розлади гормональних або ферментних систем організму, відсутність метаболізму секреторних продуктів через дефіцит вироблення певного ферменту, руйнуванням або зниженням активності метаболічної функції, які зменшують продуктивність, якість яєць і можуть призвести до загибелі птиці.

Richard J. Julian (2004) робить акцент на гіпокальціємії у несучок, які гинули без ознак захворювання, але при їх розтині діагностували стоншення стегнової та відсутність медулярної кістки, яйце без шкаралупи, яке розлите по яйцепроводу. Для профілактики остеопорозу автор рекомендує забезпечувати несучок достатньою добовою кількістю Кальцію, оскільки для утворення шкаралупи яйця потрібно 2 г Са кожні 24 години.

Е-гіповітаміноз - захворювання, що виникає при недостатньому надходженні в організм 3 кормами вітаміну Е (токоферолу) і супроводжується енцефаломаляцією, міодистрофією або ексудативним діатезом. Потреба птиці у вітаміні Е залежить від кількості та співвідношення амінокислот у раціоні. Окрім того, Е-гіповітаміноз виникає при окисненні вітаміну Е у тканинах, при нестачі селену, сульфурвмісних аміно- 
кислот (метіонін, цистин та інші), які мають синергічну щодо токоферолу дію, запобігають його окисненню. Хвороба виникає при надлишковому надходженні в організм ненасичених жирних кислот, які $є$ антагоністами вітаміну Е і містяться у великій кількості в кормових жирах. У курей за Е-гіповітамінозу різко знижується несучість, заплідненість яєць і виводимість курчат. Якщо заплідненість виникає, то такі ембріони гинуть на 3-6 добу інкубації (Panda \& Cherian, 2014).

Окрім цього, у птиці трапляються гіповітамінози вітамінів групи В та С. Вони характеризуються ураженням нервової системи, атрофією м'язів, виснаженням, порушенням білкового, жирового та вуглеводного обміну, метаболізму амінокислот, розвитком жовткового перитоніту, гепатодистрофії, зниженою виводимістю, оскільки ембріони гинуть на 16-18 день інкубації (Rakonjac et al., 2014).

За дослідженнями (Livoshchenko et al., 2014), сечокислий діатез у курей виникає внаслідок порушення протеїнового обміну i характеризується нагромадженням в організмі сечової кислоти й відкладанням iii солей в органах і тканинах. Економічні збитки, яких зазнають підприємства через цю хворобу, складаються $з$ уповільнення росту молодняку, низької оплати корму, втрати маси тіла, зниження несучості та інкубаційних властивостей яєць, загибелі птиці, вимушеного забою. Окрім цього, збитків птахівництву завдають пероз, канібалізм, аптеріоз і алопеція, гіпертермія (Levchenko et al., 2017).

Найчастіше в господарствах різних форм власності трапляється поєднаний перебіг захворювання, що у поглядах вчених (Levchenko et al., 2017) розглядається як поліметаболічна або поліморбідна патологія.

Завдяки сучасним технологіям інкубації яєць, що забезпечує високий вихід пташенят в умовах промислового виробництва, птахівництво як в Україні, так і в світі бурхливо розвивається (Trach \& Danchuk, 2018).

Широке розповсюдження в птахогосподарствах України курей сучасних високопродуктивних яєчних кросів, переважно зарубіжної селекції, призводить до появи негативних наслідків. Так, однією $з$ важливих проблем, яку необхідно розв'язати, є розробка заходів для запобігання погіршенню якості інкубаційних яєць i, як наслідок, зниженню виводимості. Погіршення якісних показників пов'язане насамперед з порушенням морфолого-біохімічних параметрів захисних біокерамічних структур яєць - шкаралупи і шкаралупних мембран, що призводить до бою яєць, підвищення відходу і контамінації інфекційними агентами молодняку птиці, зниження показників імунної резистентності, нестачі чи дисбалансу окремих макро- чи мікроелементів та вітамінів, що своєю чергою погіршує якісні показники продукції і завдає збитків птахогосподарствам, а також вимагає постійного удосконалення інкубаційних технологій (Raxmonov \& Norboev, 2019).

Якість яєчної шкаралупи залишається постійною проблемою для яєчної промисловості. Концентрація Са і Р в раціоні $є$ ключовою детермінантою міцності та ваги яєчної шкаралупи (Hamilton, 1982). Актив- ність вітаміну $\mathrm{D}_{3}$, який регулює всмоктування $\mathrm{Ca}$, модулюється гідроксилазами як у печінці, так і в нирках. У дорослих птахів знижена активність $\alpha_{1}$ гідроксилази у нирках $є$ одним 3 ключових факторів, який відповідає за зменшення використання $\mathrm{Ca}$ ( $\mathrm{Li}$ et al., 2017). Наявність Са для утворення яєчної шкаралупи залежить від розміру його частинок та активності шлунка. Приблизно 65 \% Кальцію, що поступає в організм несучок має бути у вигляді грубих частинок (> 1-2,5 мм) (Rao \& Roland,1990; Zhang \& Coon, 1997; Bouvarel et al., 2011).

Якість шкаралупи яєць та яєць загалом мають головне значення для яєчної промисловості у всьому світі (Roberts, 2004; Wu et al., 2004; Yan et al., 2019). Якість шкаралупи вимірюють за розміром, питомою вагою, кольором шкаралупи, міцністю на розбивання шкаралупи, деформацією (руйнівна чи неруйнівна), шкаралупи, товщиною та ультраструктурою шкаралупи. Внутрішня якість яєць вимірюється за кольором жовтка, цілісністю мембрани, якістю білка, вмістом каротиноїдів. На якість яєчної шкаралупи може впливати крос і вік курей; індукована линька; кормові фактори (Кальцій, Фосфор, вітаміни, якість води, некрохмальні полісахариди, ензими, забруднення кормів; стрес; система утримання). Розуміння низки факторів, які впливають на якість шкаралупи та внутрішню якість яєць, є важливим для виробництва високоякісних інкубаційних яєць, а відповідно і нормального перебігу ембріогенезу та здорового молодняку.

Guo \& Kim (2012) у своїх дослідженнях зазначають, що джерела Кальцію та розміри частинок впливають на якість шкаралупи та внутрішню якість яєць. Загальновизнано, що кожне яйце містить до 3 грамів Кальцію (Roberts, 2004), а близько 95 \% сухої шкаралупи - це карбонат кальцію. Отже, раціон курейнесучок повинен містити достатню кількість Кальцію у формі, яку можна ефективно використовувати (Roberts, 2004). Основним джерелом Кальцію в раціоні курей-несучок $\epsilon$ порошкоподібний вапняк. Велика кількість наукових праць присвячені дослідженню впливу розмірів частинок Кальцію на якість шкаралупи та внутрішню якість яєць (Zhang \& Coon, 1997; Yan et al., 2019). Однак питання впливу нестачі Са й інших поживних речовин на ембріогенез та якість молодняку залишається актуальним і нині.

Хвороби ембріонів завдають значних збитків відтворенню сільськогосподарської птиці, оскільки в ембріона будь-який патологічний процес $є$ незворотним (Levchenko et al., 2017). Відставання окремих органів у рості та розвитку не компенсується, тому виникають різноманітні аномалії. На ранніх стадіях розвитку можуть виникати патологічні зміни на окремих ділянках зародка: некрози, дистрофії. Внаслідок цього виникають агенезія та аплазія (повна відсутність закладки того чи іншого органа) або гіпогенезія і гіпоплазія (неповноцінна закладка органа). Найвища ембріональна смертність спостерігається у перші 5-7 днів (близько $15 \%$ ) та особливо на 18-20-й день розвитку (понад $50 \%$ ).

Причинами патології розвитку ембріонів можуть бути фактори незаразної, інфекційної, мікотичної, 
інвазійної етіології та порушення режиму інкубації. До незаразних причин належать аліментарні (ембріональні дистрофії) - внаслідок нестачі протеїну, вітамінів, макро- і мікроелементів; порушення режиму зберігання інкубаційних яєць; травми шкаралупи i оболонок яєць; порушення режиму інкубації - перегрів, недогрів, підвищена або знижена вологість повітря в інкубаторі, задуха, неправильне положення i переміщення яєць; генетичні аномалії.

До найпоширеніших метаболічних хвороб молодняку, які виникають внаслідок нестачі поживних речовин у раціоні маточного поголів'я птиці, належать гіповітамінози А, Д, Е, групи В, сечокислий діатез, білом'язову хворобу, пероз, аптеріоз і алопеція (Turgut et al, 2006; Levchenko et al., 2017).

За даними (Lima \& Souza, 2018), у молодняку несучок, виведених з біологічно неповноцінних за каротином та вітаміном А яєць, зріджений пух на спині і шиї, дзьоб і кінцівки бліді, щілина ока напіввідкрита, сльозотеча і злипання повік, пупкове кільце не закрите, загальне пригнічення, малорухливість, сонливість, відсутність апетиту і нервові явища.

Розвиток рахіту в курчат виникає внаслідок неповноцінності інкубаційних яєць щодо вітамінів A i D, надмірної вологості у пташнику, відсутності моціону і зелених кормів у раціоні На рахіт хворіє найчастіше молодняк 1-5-місячного віку і характеризується кволістю курчат, зниженням апетиту, анемією, скуйовдженістю пір'я, птиця більше сидить, а потім зовсім втрачає здатність рухатись (Turgut et al., 2006).

Провівши аналіз літературних джерел, хочемо зазначити, що розвиток яєчного птахівництва ставить перед спеціалістами ветеринарної медицини завдання своєчасної діагностики хвороб курей-несучок, розробки методів їх лікування та профілактики.

\section{Висновки}

Метаболічні хвороби курей-несучок поширені в господарствах усіх форм власності та потребують ранньої діагностики, розробки методів групової неспецифічної профілактики, зокрема маточного поголів'я, з метою отримання якісних інкубаційних яєць, зниження економічних збитків на стадії ембріогенезу, підвищення виводимості, якості та отримання здорового молодняку високопродуктивних кросів сільськогосподарської птиці.

\section{Відомості про конфлікт інтересів}

Автори стверджують про відсутність конфлікту інтересів.

\section{References}

Antonenko, P. P., Kovalova, I. V., Chornyi, M. V., Harnazhenko, Yu. A., \& Pushkar, T. D. (2017). Biokhimichni pokaznyky krovi kurei-nesuchok za vplyvu selenitu natriiu ta kormovykh fitopreparativ. Ahrarna nauka ta kharchovi tekhnolohii, 3(97), 3-10. URL: http://nbuv.gov.ua/UJRN/anxt_2017_3_3 (in Ukrainian).
Bashchenko, M. I., Boiko, O. V., Honchar, O. F., Gutyj, B. V., Lesyk, Y. V., Ostapyuk, A. Y., Kovalchuk, I. I., \& Leskiv, Kh. Ya. (2020). The effect of milk thistle, metiphen, and silimevit on the protein-synthesizing function of the liver of laying hens in experimental chronic cadmium toxicosis. Ukrainian Journal of Ecology, 10(6), 164-168. doi: 10.15421/2020_276.

Bicudo, J. E. P. W., Buttemer, W. A., Chappell, M. A., Pearson, J. T., \& Bech, C. (2010). Ecological and Environmental Physiology of Birds. (1st ed.) Oxford University Press. doi: 10.1093/acprof:oso/9780199228447.001.0001.

Bilokon, O. V., Mazurkevych, A. I., Karpovskyi, V. I., Trokoz, V. O., Kryvoruchko, D. I., \& Zhurenko, O. V. (2010). Vplyv mineralnoi kormovoi dobavky "Kormatsynk-R" na obminni protsesy v orhanizmi kurei. Naukovyi visnyk Lvivskoho natsionalnoho universytetu veterynarnoi medytsyny ta biotekhnolohii imeni S. Z. Gzhytskoho, 12(2(44)), 10-13. URL: https://cyberleninka.ru/article/n/vpliv-mineralnoyikormovoyi-dobavki-kormatsink-p-na-obminniprotsesi-v-organizmi-kurey (in Ukrainian).

Bouvarel, I., Nys, Y., \& Lescoat, P. (2011). Hen nutrition for sustained egg quality. In Improving the safety and quality of eggs and egg products. Egg Chemistry, Production and Consumption. Woodhead Publishing Series in Food Science, Technology and Nutrition. doi: 10.1533/9780857093912.3.261.

Derzhavna sluzhba statystyky Ukrainy. URL: http://ukrstat.gov.ua (in Ukrainian).

Dunkley, C. (2009). Important Nutritional Diseases that Affect Laying Hens https://www.thepoultrysite.com/ articles/important-nutritional-diseases-that-affect-layinghens.

Guo, X. Y., \& Kim, I. H. (2012). Impacts of Limestone Multi-particle Size on Production Performance, Egg Shell Quality, and Egg Quality in Laying Hens. Asian-Australasian Journal of Animal Sciences, 25(6), 839. doi: 10.5713/ajas.2011.11468.

Gutyj, B. V., Ostapyuk, A. Y., Sobolev, O. I., Vishchur, V. J., Gubash, O. P., Kurtyak, B. M., Kovalskyi, Y. V., Darmohray, L. M., Hunchak, A. V., Tsisaryk, O. Y., Shcherbatyy, A. R., Farionik, T. V., Savchuk, L. B., Palyadichuk, O. R., \& Hrymak, K. (2019). Cadmium burden impact on morphological and biochemical blood indicators of poultry. Ukrainian journal of Ecology, 9(1), 235239. URL: https://www.ujecology.com/ articles/cadmium-burden-impact-on-morphological-andbiochemical-blood-indicators-of-poultry.pdf.

Hamilton, R. M. (1982). Methods and factors that affect the measurement of egg shell quality. Poultry Science, 61(10), 2022-2039. doi: 10.3382/ps.0612022.

Hansen, R. J., \& Walzem, R. L. (1993). Avian fatty liver hemorrhagic syndrome: a comparative review. Adv Vet Sci Comp Med., 37, 451-468. URL: https://pubmed.ncbi.nlm.nih.gov/8273524.

Horzheiev, V. M. (2014). Problemy zabezpechennia veterynarnoho blahopoluchchia tvarynnytstva. Naukovyi visnyk veterynarnoi medytsyny: zbirnyk naukovykh prats. Bila Tserkva, 13(108), 5-9 (in Ukrainian).

Jefferson, R. (2005). Production and growth related disorders and other metabolic diseases of poultry - A re- 
view. The Veterinary Journal, 169(3), 350-369. doi: 10.1016/j.tvj1.2004.04.015.

Julian, R. J. (2005). Production and growth related disorders and other metabolic diseases of poultry $-\mathrm{A}$ review. The Vet. J., 169, 350-369. doi: 10.1016/j.tvj1.2004.04.015.

Kernasiuk, Yu. (2018). Rynok miasa: osnovni trendy. Ekonomichnyi hektar. URL: http://agrobusiness.com.ua/agro/ekonomichnyi-hektar/item/11153rynok-miasa-osnovni-trendy.html (in Ukrainian).

Kopytets, N. H., \& Voloshyn, V. M. (2016). Otsinka tsinovoi sytuatsii na rynku miasa ptytsi. Ekonomika APK, 11, 42-49. doi: 10.32317/2221-1055.201911042 (in Ukrainian).

Kyryliv, B. Ya., \& Ratych, I. B. (2001). Vmist zahalnykh lipidiv i spivvidnoshennia yikh okremykh klasiv $u$ plazmi krovi i tkanyni pechinky kurei-nesuchok za riznoi kilkosti lipidiv ratsionu. Naukovo-tekhnichnyi biuleten Instytutu biolohii tvaryn, 1-2, 21-26 (in Ukrainian).

Lee, K., Flegal, C. J., \& Wolford, J. H. (1975). Factors affecting liver fat accumulation and liver haemorrhages associated with fatty liver haemmorhagic syndrome in laying chickens. Poult. Sci., 54(2), 374-380. doi: 10.3382/ps.0540374.

Leeson, S. (1999). Considerations for using enzymes in poultry nutrition. Intern. Symp. On Poult. Nutr. Proc. FACTA. Brasil, 73-186.

Levchenko, V. I., Kondrakhin, I. P., \& Vlizlo, V. V. (2017). Vnutrishni khvoroby tvaryn [tekst]: pidruchnyk. Bila Tserkva (in Ukrainian).

Levchenko, V. I., Vlizlo, V. V., \& Kondrakhin, I. P. (2019). Veterynarna klinichna biokhimiia: pidruchnyk. Bila Tserkva (in Ukrainian).

Li, X., Zhang, D., \& Bryden, W. L. (2017). Calcium and phosphorus nutrition of poultry: are modern diets formulated in excess? Animal Production Science, 57(11), 2304-2310. doi: 10.1071/AN17389.

Lima, H. J. D., \& Souza, L. A. Z. (2018). Vitamin A in the diet of laying hens: enrichment of table eggs to prevent nutritional deficiencies in humans. World's Poultry Science Journal, 74(4), 619-626. doi: 10.1017/S004393391800065X.

Livoshchenko, Ye. M., Kambur, M. D., \& Livoshchenko, L. P. (2014). Anatomichni i hematolohichni osoblyvosti zmin pry sechokyslomu diatezi u molodniaka kurei. Visnyk Sumskoho natsionalnoho ahrarnoho universytetu, seriia "Veterynarna medytsyna", 6(35), 42-47. URL: http://repo.snau.edu.ua/bitstream/123456789/1932/1/ано томічні\%20та\%20гематологічні\%20особливочтіДоку мент\%20Microsoft\%200ffice\%20Word.pdf (in Ukrainian).

Lopatyn, L. V. (2012). Stan ta perspektyvy rozvytku ptakhivnytstva v Ukraini. Ahrarnyi visnyk Prychornomor'ia, 65, 42-46 (in Ukrainian).

Mashkin, Yu. V. (2010). Hematolohichni ta biokhimichni pokaznyky krovi kurchat-broileriv pid vplyvom probiotyka "Protekto-Aktyv". Suchasne ptakhivnytstvo, 1-2 (86-87), 26-27 (in Ukrainian).

Meleniuk, S. (2021). Ptakhivnytstvo Ukrainy ta Polshchi. Zhurnal "Nashe ptakhivnytstvo", 1(73), 14-17 (in Ukrainian).
Melnyk, A. Iu. (2015). Analiz i perspektyvy haluzi ptakhivnytstva Ukrainy, poshyrennia ta klasyfikatsiia metabolichnykh khvorob silskohospodarskoi ptytsi. Naukovyi visnyk veterynarnoi medytsyny, 2, 67-73. URL: http://nbuv.gov.ua/UJRN/nvvm_2015_2_14 (in Ukrainian).

Melnyk, A. Yu. (2008). Kliniko-biolohichne obgruntuvannia metodiv diahnostyky ta profilaktyky porushen fosforo-kaltsiievoho obminu i D-vitaminnoho obminiv u kurei-nesuchok: avtoref. dys. kand. vet. Nauk. Bila Tserkva (in Ukrainian).

Novozhylova, Ye. V. (2014). Vymohy YeS do kormiv pry importi produktsii tvarynnytstva. Jekskljuzivnye tehnologii, 1(28), 51-53 (in Ukrainian).

Ostapyuk, A., \& Gutyj, B. (2019). Influence of cadmium sulfate at different doses on the functional state of the liver of laying chicken. Scientific Messenger of LNU of Veterinary Medicine and Biotechnologies. Series: Veterinary Sciences, 21(94), 103-108. doi: 10.32718/nvlvet9419.

Ostapyuk, A. Y., Holubieva, T. A., Gutyj, B. V., \& Slobodian, S. O. (2021). The effect of sylimevit, metifen, and milk thistle on the intensity of the processes of peroxidation of lipids in the body of laying hens in experimental chronic cadmium toxicosis. Ukrainian Journal of Ecology, 11(4), 57-63. doi: $10.15421 / 2021199$.

Panda, A. K., \& Cherian, G. (2014). Role of Vitamin E in Counteracting Oxidative Stress in Poultry. J. Poult. Sci., 51(2), 109-117. doi: 10.2141/ jpsa.0130134.

Rakonjac, S., Bogosavljević-Bošković, S., Pavlovski, Z., Škrbić, Z., Dosković, V., Petrović, M. D., \& Petričević, V. (2014). Laying hen rearing systems: a review of major production results and egg quality traits. Worlds Poultry Science Journal, 70(1), 93. doi: $10.1017 /$ S0043933914000087.

Rao, K. S., Roland, D. A. (1990). In vivo limestone solubilization in commercial Leghorns: role of dietary calcium level, limestone particle size, in vitro limestone solubility rate, and the calcium status of the hen. Poultry Science 69(12), 2170-2176. doi: 10.3382/ps.0692170.

Raxmonov, U.A., \& Norboev, Q. N. (2019). Etiopathogenesis and prevention of hypovitaminosis of chicken. An International Multidisciplinary Research Journal, 9(1), 95-100. doi: 10.5958/2249-7137.2019.00012.0.

Roberts, J. R. (2004). Factors Affecting Egg Internal Quality and Egg Shell Quality in Laying Hens. The Journal of Poultry Science, 41(3), 161-177. doi: 10.2141/jpsa.41.161.

Semenenko, M., Kuzminova, E., Grin, V., Rogaleva, E., \& Semenenko, K. (2020). Possibilities of using natural aluminosilicates in the development of medicines at hepatosis in poultry. E3S Web of Conferences, 175, 04002.

Soiuz ptakhivnykiv Ukrainy. URL: http://www.poultryukraine.com/ (in Ukrainian).

Stoyanovskyy, V., Shevchuk, M., Kolomiiets, I., \& Kolotnytskyy, V. (2020). Dynamics of individual indicators of protein metabolism in the body of broiler chickens on the background of combined stress when included in the diet "Reasil Humic Vet" + "Laktin" and "Reasil Humic Health". Ukrainian Journal of Vet- 
erinary and Agricultural Sciences, 3(2), 42-46. doi: 10.32718/ujvas3-2.07.

Tilbrook, A. J., \& Fisher, A. D. (2020). Stress, health and the welfare of laying hens. Animal Production Science, 61(10), 931-943. doi:10.1071/AN19666.

Trach, V. V., \& Danchuk, V. V. (2018). Vplyv khimichnoi obrobky inkubatsiinykh yaiets na vmist vitaminiv A i E u pe-chintsi perepela. Ahrarna nauka ta osvita $v$ umovakh yevrointehratsii: zb. nauk. prats za materialamy mizhnar. nauk.-prakt. konf. (m. Kam'ianetsPodilskyi, 20-22 ber. 2018 r). Kam'ianets-Podilskyi, 428-430 (in Ukrainian).

Tsaruk, L. L. (2017). Suchasnyi stan vyrobnytstva produktsii ptakhivnytstva v Ukraini. Suchasni problemy selektsii rozvedennia ta hihiieny tvaryn, 1(95), 159-170. URL: http://socrates.vsau.org/repository/ card.php?lang=en\&id=19381 (in Ukrainian).

Turgut, L., Hayirli, A., Çelebi, Ş., Akif Yoruk, M., Gul, M., Karaoglu, M., \& Macit, M. (2006). The effects of vitamin $\mathrm{D}$ supplementation to peak-producing hens fed diets differing in fat source and level on laying performance, metabolic profile, and egg quality. August, Asian Australasian Journal of Animal Sciences, 19(8), 1179-1189. doi: 10.5713/ajas.2006.1179.

Underwood, G., Andrews, D., \& Phung, T. (2021). Advances in genetic selection and breeder practice improve commercial layer hen welfare. Animal Production Science. 61(10) 856-866. doi: 10.1071/AN20383.

Verbytskyi, S., \& Shevchenko, V. (2008). Ptakhivnytstvo: suchasnyi stan ta prohnozy. Ptakhivnytstvo, 4-7 (in Ukrainian).

Verner, A. (2013). Racional'nyj podhod k ispol'zovaniju kormovyh dobavok $\mathrm{v}$ racionah pticy. Tvarinnictvo s'ogodni, 8, 41-42 (in Russian).

Vodolazhchenko, S. (2011). Kormovye faktory vyzyvajut zabolevanija pticy. Kormi i fakti, 8(12), 22-23 (in Russian).

Wu, Y. B., Ravindran, V., Thomas, D. G., Birtles, M. J., \& Hendriks, W. H. (2004). Influence of method of whole wheat inclusion and xylanase supplementation on the performance, apparent metabolisable energy, digestive tract measurements and gut morphology of broilers British Poultry Science 45(3), 385-394. doi: 10.1080/00071660410001730888.

Yan, F., Murugesan, G., \& Cheng, H. (2019). Effects of probiotic supplementation on performance traits, bone mineralization, cecal microbial composition, cytokines and corticosterone in laying hens. Animal, 13, 33-41. doi: 10.1017/S175173111800109X.

Yaremchuk, V. Y., \& Slivinska L. G. (2019). Influence of hepatoprotectors on the functional state of the liver in laying hens with hepatosis. Science and Education a New Dimension. Natural and Technical Sciences, VII (26), Issue: 215.

Yaremchuk, V., Slivinska, L., \& Stronskyi, Y. (2020). Morphological particulars of the liver of laying hens of cross "Lohmann Brown" under hepatosis. Scientific Messenger of LNU of Veterinary Medicine and Biotechnologies. Series: Veterinary Sciences, 22(97), 69 73. doi: $10.32718 /$ nvlvet9712.

Yousefi, M., Shivazad, M., \& Sohrabi-Haghdoost, I. (2005). Effect of Dietary Factors on Induction of Fatty Liver-Hemorrhagic Syndrome and its Diagnosis Methods with Use of Serum and Liver Parameters in Laying Hens. Int J Poult Sci., 4(8), 568-572. doi: 10.3923/ijps.2005.568.572.

Zang, H., Zhang, K., Ding, X., Bai, S., Hernández, J. M., \& Yao, B. (2011). Effects of different dietary vitamin combinations on the egg quality and vitamin deposition in the whole egg of laying hens. Braz. J. Poult. Sci., 13(3), 189-196. doi: 10.1590/S1516635X2011000300005.

Zhang, B., \& Coon, C. N. (1997) The relationship of calcium intake, source, size, solubility in vitro and in vivo, and gizzard limestone retention in laying hens Poultry Science, 76(12), 1702-1706. doi: 10.1093/ps/76.12.1702.

Zon, H. A., \& Ivanovska, L. B. (2016). Dbaite pro pechinku ptytsi - dosiahnete uspikhu $\mathrm{v}$ ahrobiznesi. Kormy i fakty, 8(72), 26-28. URL: https://agro.press/storage/journal/41/parts/424/03e4ef7 e1178f027a666056b32e7bf8b.pdf (in Ukrainian). 